\title{
(Im)Possibility of Learning Science Through Livelihood Activities at Community Schools in Nepal
}

\author{
Kamal Prasad Acharya ${ }^{1}$, Rajani Rajbhandary ${ }^{2} \&$ Milan Acharya $^{3}$ \\ ${ }^{1}$ Central Department of Education, University Campus, Tribhuvan University, Kirtipur, Kathamndu, Nepal \\ ${ }^{2}$ Department of Science Education, Sanothimi Campus, Tribhuvan University, Nepal \\ ${ }^{3}$ Department of Health and Population Studies, Sanothimi Campus, Tribhuvan University, Nepal \\ Correspondence: Kamal Prasad Acharya, Department of Science and Environment Education, Central \\ Department of Education, University Campus, Tribhuvan University, Kirtipur, Kathmandu, Nepal. Tel: \\ 98-4139-5628. E-mail: kamalacharya@tucded.edu.np
}

Received: April 11, 2019

doi:10.5539/ass.v15n6p88
Accepted: May 4, 2019 Online Published: May 31, 2019

URL: https://doi.org/10.5539/ass.v15n6p88

\begin{abstract}
The Science in the Learning Home (SciLH) program was designed to address two well-documented, inter-related educational problems observed in the Community High Schools in Nepal. The first relates to the achievement of students in science in Secondary Education Examination (SEE), which is below average (33 out of 75 i.e. $44 \%$ ), and the second concerns the insufficiencies of the resources and instruction to discourse their traditional and livelihood requirements through school science learning activities. Funded by the University Grants Commission (UGC), Nepal, as a Small Research Development and Innovation Grants (SRDIG) to the faculty member, SciLH is a title set by the researcher to provide a new and innovative concept to learn science from the home and cultural practices. The tenth-grade high school students and the community people (parents) participated in the study. Livelihood practices and activities at the home link SciLH concept aligns with the school science curriculum and textbooks with that of cultural practices. This research article offers a framework to explore factors which support the accomplishment of the ethnically different student population and parents using the outline of ethno-perspective.
\end{abstract}

Keywords: livelihood practices, performance, science learning home

\section{Introduction}

There is a growing concern among policy-makers and practitioners in Nepal about the decreasing high school performance in the science subjects among the students in District Level Examination (DLE) and SEE. Research shows us inadequacies in the teaching and learning science by students in community schools, resulting in the widening of an achievement gap between the students of community and institutional school students. Large gaps in access to high-quality science teaching and learning and also doing hands-on activities disproportionately impact students studying in the community and institutional high schools.

In the community schools of Nepal, traditional teaching-learning approaches i.e., chalk and talk method of teaching is in practice. Students discussions are less encouraged by the science teachers and the students are expected to be the passive receivers of the teacher's poured content knowledge without its real meaning to life activities. In this context, science teachers usually found to be solving the problems of science on the board and students receive teachers' poured content knowledge throughout the class period. Meaningless manipulation of formulas and symbols of elements or chemical reactions are found in practice in the classrooms (Hong \& Talib, 2018; Liou \& Jessie, 2018; Vedder-Weiss \& Fortus, 2018). The practice of the dogmatic approach to teaching science makes students experience monotony and students stereotypically memorize contents as a procedure without any rationale meaning of the contents.

These inequalities are exclusively disturbing since investigation displays that disengagement in science classes due to lack of activities and so students lose interest and do not develop connections in daily life experiences and the science subject at tenth grade, they are not willing to enroll them in advanced learning courses in the universities. To address these anxieties, researchers have called for activity-based instruction (Acharya, 2018; Adejimi, 2019; Chowdhury, 2018), real-life active learning (Chen, 2019), and social contexts that facilitate 
motivation, engagement, and the development of a positive academic identity (Hussin, JHarun, \& Shukor, 2019; Rouse, 2018). This scenario led school science teachers to engage high school pupils with real-life problems through intellectually challenging learning activities within motivationally supportive social and cultural settings of the communities.

Research funded by the University Grants Commission under Small Research Development and Innovation Grants (SRDIG) to the faculty member, conducted a research study entitled 'learning science beyond the classrooms in Nepal: an ethno-perspective'. Based on this research report, Science in the Learning Home (henceforth, SciLH) has emerged that can address the needs of high schools students in the science subject and investigate how the cultural practices performed in the community might offer a supportive environment to engage students to understand the basic scientific concepts leading to constructive and better outcomes in science in DLE and SEE. The research reported here draws upon this study, which provides a home-based curriculum and instruction for tenth-grade community high school students.

Informed to parents for activity-based instruction at home called SciLH uses day-to-day life activities for livelihood such as learning the concept of simple machines while using 'Dhiki' (domestically made rice beating machine made of a wooden log), understanding the basic concept of wheel and axle from 'Janto' (home made grinding stone), accepting the basic concept of the third class lever while using 'Silauta' (garlic crusher), the basic but the major concept of simple machines while using 'Kucho' (broom) for sanitation, application of turmeric powder in the vegetables as an antiseptic (chemical concept) and understanding evaporation while shedding grains in sunlight.

Furthermore, livelihood practices are helpful to convey the message of basic science concepts to the students and can be linked with the science curriculum. Community livelihood practices are regarded as contexts for hands-on, pragmatic, and general science learning activities. The study draws upon the self-motivation of students at home to gain the basic science concepts from home, that can be linked with the content in the science textbooks formally as well as informally (Acharya, Devkota, Budhathoki, \& Bjonness, 2018; Engestrom, 2017). SciLH anticipates supporting the progress of students' science distinctiveness, science engagement, science wisdom, and success.

\subsection{Science Learning Through the SciLH Program}

Science learning beyond the classrooms is a recent trend to learn science in the context of Nepal. The outdoor classroom i. e., the SciLH provides a meaningful way to engage the students in home-based practical activities, giving them real-life understanding of accumulating and investigating facts, and making extrapolations in the real realm, beyond the boundaries of the science schoolroom or science laboratory. SciLH also builds the environment including the teamwork among the family members, motivate them and its powerful influence definitely marks the choice of science as a future career of study to contribute to the nation. Providing students with real quality learning activities in relevant situations beyond the walls of the classroom is vital for helping them appreciate their first hand experiences while working in the kitchen, involving in household activities such as cleaning, washing, cutting and sharing, and so on forms a variety of different perspectives (Black, Weiler \& Chen, 2019; Hargreaves, Wilson \& Hauxwell-Baldwin, 2018; James, \& Williams, 2017). Experiences outside the classroom enhance learning by providing students with opportunities to practice skills of enquiry, values analysis and clarification and problem solving in everyday situations.

Socially responsive science pedagogy begins from home and community practices with the assumption of learning science through the ethno-science perspective. It starts with an appreciation in daily life activities and traditional practices for community livelihood pattern (Dewey, 1998; Kelly \& Licona, 2018). This perspective views the engaged and lived experiences of students as strengths, capitalizing on 'the rich and varied cultural wealth, knowledge, and skills that diverse students bring to schools' (Alim, Sarwi, \& Subali, 2020; Rahmawati, Subali, \& Sarwi, 2018). The essential elements of socially responsive pedagogy comprises appreciating pupils' assets, linking learning to students' daily live activities in the community, nurturing constructive parent-teacher relationships and shifting the power dynamics between educators and learners as well as parents and teachers.

The home-based science learning program, i.e. SciLH activities show promise as meaningful, socially responsive, meet the real-life problems, supportive contexts for promoting students' meaningful engagement and help to understand the basic scientific concepts. Such home-based science learning activities help to upgrade students overall performance in science (Alim, Sarwi, \& Subali, 2020; Sudarmin, Selia, \& Taufiq, 2018; Sumarni, 2018). Many research studies claim that home-based science learning programme has a positive effect on a variety of academic outcomes in science along with meaningful livelihood practices. It is found that for those students who participated in hands-on science learning at home have comparatively good science achievement scores than 
those who are studying only at the school classrooms. Furthermore, it is concluded that real and engaged participation of students along with the parents on hands-on activities and linking these activities with the science classrooms is the main feature of SciLH. Hence, I can claim from this study that home is a living laboratory where community high school students can understand what they are learning and in turn, apply that community wisdom and knowledge to everyday circumstances.

Engagement of high school students in the community livelihood practices help them to understand the scientific cause and effect relation in every action happening at the daily life activities. It is the milestone for personal transformation in a student's understanding of livelihood patterns and ultimately upgrading their academic performance.

\section{Research Methodology}

Data were drawn from four community high schools located at rural and urban areas. A total of 340 students were participating in the study among which $184(57.1 \%)$ students from the rural schools and $146(43.1 \%)$ from the urban schools. All the tenth-grade students took part in SciLH home-based cultural and livelihood practices and activities with the parents in 2019.

Students were rated their agreement with Likert-type survey items on a rating scale from 0 to 5 (strongly disagree, disagree, don't know or neutral, agree and strongly agree). All the students' were supported by their parents from both the urban and rural schools located in province no. 2 and 5 of federal Nepal. They are integrating science themes in daily community livelihood practices such as kitchen practices, grain conservation techniques, and application of herbal plants and the extracts for medicinal applications at home and in the community. These activities motivate high school students to understand basic science concepts linked with the curriculum. The home practices serve as an extension of the schools' classroom beyond the formal classrooms to study science at high schools. Besides acquiring basic livelihood skills, students discovered their connections to the place-based learning along with the ethno-science practices.

A set of opinnionaire having five distractors (strongly agree, agree, don't know/neutral, disagree and strongly disagree) based on five points Likert's scale which is given to the students about the science classroom practices, linkage between the indigenous knowledge and the classroom activities along with the parents friendly environment.

\subsection{Population and Sample of the Study}

Table 1. Type of sample schools and the school codes

\begin{tabular}{cccc}
\hline Type of School & Code of School & Students & $\%$ \\
\hline Community & School CA & 92 & 27.1 \\
Community & School CB & 72 & 21.2 \\
Institutional & School IA & 102 & 30.0 \\
Institutional & School IB & 74 & 21.8 \\
Total & & 340 & 100 \\
\hline
\end{tabular}

A total of 340 students (Table 1) from two community high schools and two institutional schools have been sampled to this study. Total numbers of the participants were 340 who help to ensure learning by the use of opinionative to understand the basic concepts and science learning activities outside the classrooms in Nepal.

\section{Results}

\subsection{Descriptive Statistics}

First, the reliability of the scales used in this study was computed. The reliability for the different scales based on the pre-test and the post-test, measured by Cronbach's alpha, is presented in Table 6. The reliability for the different scales was deemed sufficient for the purpose of this research, although the Likert like scale 'assessment of engaged learning at home' resulted in a rather low Cronbach's alpha for the pre-test.

Table 2. Descriptive statistics on scales with Cronbach's alpha

\begin{tabular}{|c|c|c|c|}
\hline Item example & Scales & Condition & Cronbach's alpha \\
\hline \multirow{2}{*}{$\begin{array}{l}\text { I learn the concept of first class level while using 'Dhiki' } \\
\text { (Rice beater). }\end{array}$} & Agree & Pre-test & 0.642 \\
\hline & Strongly agree & Post-test & 0.753 \\
\hline \multirow{2}{*}{$\begin{array}{l}\text { I understand wheel and axle from 'Janto' (stone } \\
\text { grinder). }\end{array}$} & Undecided & Pre-test & 0.865 \\
\hline & Agree & Post-test & 0.915 \\
\hline
\end{tabular}




\begin{tabular}{llll}
\hline I understand third class level while using 'Silauta' (garlic & Agree & Pre-test & 0.644 \\
crusher). & Strongly agree & Post-test & 0.760 \\
I can better understand simple machine while using & Agree & Pre-test & 0.635 \\
'Kucho' (Broom). & Strongly agree & Post-test & 0.742 \\
I use turmeric power in curry as an antiseptic. & Agree & Pre-test & 0.762 \\
& Strongly agree & Post-test & 0.810 \\
I understand evaporation while shedding grains in & Disagree & Pre-test & 0.645 \\
sunlight. & Agree & Post-test & 0.782
\end{tabular}

Total $n=340$. Scales range from 0 (strongly disagree) to 5 (strongly agree).

Table 2 presents the descriptive statistics for the variables measured as well as for the change in science activities in the household environment. The result indicates that, when starting the basic science concepts at home, students adopt more a deep than a surface approach. Learning science from the community livelihood practices, students adopt more and real concepts of science than surface approaches read in the textbooks. In general, it is shown that Cronbach's alpha is increasing in the post-test. The results in Table 2 indicates that, when starting the learning science concepts at home and the community practices, students adopt more and depth knowledge than a surface what they obtained at the school through cookbook approach. In general, students perceive the real scientific concepts from the home and livelihood practices as more depth than rote learning in the structured classrooms in the high schools.

\subsection{Correlations Among Tenth-Grade Students in Science After the SciLH Practices}

Correlations among tenth-grade student are given in Table 3. As expected, the five basic science concepts are positively correlated through household activities in collaboration with the parents which are significantly correlated.

Table 3. Correlations within basic science concepts and learning engagement

\begin{tabular}{cccccc}
\hline $\begin{array}{c}\text { Basic science } \\
\text { concept }\end{array}$ & $\begin{array}{c}\text { Dhiki- a simple } \\
\text { machine }\end{array}$ & $\begin{array}{c}\text { Wheel and axle } \\
\text { from Janto }\end{array}$ & $\begin{array}{c}\text { Third class lever } \\
\text { Silauta }\end{array}$ & $\begin{array}{c}\text { Kucho \& simple } \\
\text { machine }\end{array}$ & $\begin{array}{c}\text { Turmeric power as an } \\
\text { antiseptic }\end{array}$ \\
\hline $\begin{array}{c}\text { Motivation in } \\
\text { activities } \\
\begin{array}{c}\text { Meaningful } \\
\text { engagement }\end{array}\end{array}$ & $-0.2^{\text {ns }}$ & 0.56 & 0.51 & $0.21^{* *}$ & 0.57 \\
$\begin{array}{c}\text { Link with the } \\
\text { curriculum }\end{array}$ & 0.71 & 0.54 & 0.79 & $0.16^{* *}$ & 0.64 \\
$\begin{array}{c}\text { Parents support } \\
\text { Achievement }\end{array}$ & 0.89 & 0.68 & 0.87 & $0.12^{* *}$ & 0.75 \\
\hline
\end{tabular}

Total $\mathrm{n}=340$. Correlations for concept variables of $10^{\text {th }}$ grade community school students; All coefficients are significant at $\mathrm{p}$ $<.001$ unless otherwise indicated; ${ }^{*} \mathrm{p}<.05 ;{ }^{* *} \mathrm{p}<.01 ;$ ns not significant

Tenth-grade students' science concepts showed good correlations that suggest the interconnected relations between science achievement and day to day community practices to understand the basic science concepts. Students motivation, meaningful engagement and linking the concept in the curriculum with the application of 'Kucho' as a simple machine show weak correlation and did not reach the significance level. Also, motivation with activities while using 'Dhiki' as a simple machine shows no significant difference.

The major findings show that the community people from the study area are practicing different science concepts in relation to cooking practices, grain conservation, and use of medicinal plants in the community. While preparing food there are a lot of science concepts such as evaporation, condensation, distillation, states of matter, molecular concentration in ice cubes, acid-base reactions, use of ash for washing clothes, etc. It was found that many practices of community people such as shedding grains in sunlight; applying ash and herbal medicines such as 'Neem' (Azadirachta indica) plant leaves water in food items to store for a long time and application of herbal plant 'Titepati' (Artemisia vulgaris) to remove insects while storing grains for a long time. The result showed that classroom interaction regarding this matter to understand science concepts is good among the rural community school students (N 23) as they are strongly agreed than that of the students studying at urban schools (N 9).

Overall, classroom interaction among high school students is good (N 152). Sharing classwork and homework among the friends in rural community school is better than that of urban schools. A large number (N 149) of 
community school students are studying in a collaborative way than those who study science at the urban schools (N 55). Students from the institutional high schools are focused more on recitation and do not believe on collaborative learning environments.

Students opinion of the teachers' encouragement to the students' learning activities was disagreed (N 127) and strongly disagreed $(\mathrm{N} 43)$ in both the type of schools in rural and urban areas. It shows that science teachers need some professional development training to respect and motivate students to learn science in groups and from the community practices. In both the community and institutional schools, the maximum number (N 226) of students lacking basic ideas and knowledge of studying science subject and its real concepts through school gardening activities. In relation to school gardening activities, $10.3 \%$ of students are strongly disagreed and $24.1 \%$ of students have disagreed that science teachers listen to them when they raise questions in science teaching and learning activities. Whereas, only $7.4 \%$ of students are strongly agreed and $52.9 \%$ of students are agreed to respond to the query of students. A large number $(54.1 \%)$ of high school students enjoy science class, $7.9 \%$ undecided on the statement. However, only $11.5 \%$ of students are strongly disagreed that they feel science class boring.

Science teachers' positive behaviour was optioned by 121 boy and 78 girl students. Thirty five male and female students of each have disagreed that there is no discrimination by gender. But, only 32 students are undecided on this statement. It shows that discrimination of sex is common in science classes in both the community and institutional schools located in rural and urban areas. 112 boys are agreed to enjoy the science class whereas only 72 female students enjoy the same. $7.5 \%$ boys and $8.6 \%$ of girls are not aware of enjoying science classes. To link the science teaching and learning by the use of local herbal plant 'Neem' to the students, most of them have responded that it was used to cure diarrhoea, some of them have responded to cure stomachache and very few have answered to cure scabies. A total of 102 students have responded 'don't know' about the application of such Ayurvedic plants in our daily life. Most of them are from the institutional schools from urban and rural areas. In the query of using the soup of 'Aniseed' to the sick person and for the pregnant as well as the lactating mother, very few of them have responded that it makes the bone and teeth strong as it is the good source of calcium. Only a few respondents have no ideas about the application and use of aniseed. This shows us that the concept of science teaching and learning in the schools in Nepal does not strongly link to the knowledge of the community what we have and where they are grown up. The culture of studying science is only based on the content of the text books but not linking the basic science concepts with the science curriculum. We are strictly based on the textbook and not on the facts, figures as well as the knowledge we have around our society.

\section{Discussion}

\subsection{Background Characteristics of Research Participants}

All 340 tenth-graders from four schools were participating in this study. Parental consent was received for all the students and school head teachers before starting the data collection through students' opinion. Information of students as per the religion indicated that boys and girls were $58.5 \%$ and $41.5 \%$ respectively. $57.1 \%$ students have a nuclear family whereas $42.9 \%$ were living in an extended family with the grandparents, uncles and aunties. Majority of students follow Hinduism (54.1\%), 23.8\% were Buddhists, 6.2\% were Christian, and 8.8\% are Muslim and the remaining 7.1 are others. In addition, there is a diversity of ethnic composition. $13.8 \%$ were Brahmin, 26.2\% were Chhetis, 11.8\% were Gurung/Magar, 34.4\% were Newar, 7.1\% were Tharus, and 7.2\% were others. In the same way, $35.6 \%$ of the students spoke the Nepali language as the mother tongue; $19.4 \%$ were Newari, 18.4\% were using Rai language and 4.1\% speak Tharu language as their mother tongue.

Table 4. Background characteristics of the respondents

\begin{tabular}{cccc}
\hline \multirow{2}{*}{ Background characteristics } & \multicolumn{2}{c}{ Total } \\
\cline { 3 - 4 } \multirow{3}{*}{ School } & School CA & $\mathrm{N}$ & 27.1 \\
& School IB & 92 & 21.1 \\
& School CB & 74 & 21.2 \\
& School IA & 102 & 30 \\
\hline \multirow{2}{*}{ Gender } & Male & 201 & 58.5 \\
& Female & 139 & 41.5 \\
\hline \multirow{2}{*}{ Type of family } & Nuclear & 197 & 57.1 \\
& Extended & 143 & 41.4 \\
\hline Religion & Hindu & 184 & 54.1 \\
\hline
\end{tabular}




\begin{tabular}{|c|c|c|c|}
\hline & Buddhist & 81 & 23.8 \\
\hline & Christian & 21 & 6.2 \\
\hline & Muslim & 30 & 8.8 \\
\hline & Others & 24 & 7.1 \\
\hline \multirow{6}{*}{ Caste } & Brahmin & 47 & 13.8 \\
\hline & Chhetris & 89 & 26.2 \\
\hline & Gurung/Magar & 38 & 11.2 \\
\hline & Newar & 117 & 34.4 \\
\hline & Tharu & 24 & 7.1 \\
\hline & Others & 25 & 7.2 \\
\hline \multirow{6}{*}{ Language } & Nepali & 121 & 35.6 \\
\hline & Newari & 66 & 19.4 \\
\hline & Gurung & 63 & 18.5 \\
\hline & Rai & 15 & 4.4 \\
\hline & Tharu & 47 & 13.8 \\
\hline & Others & 28 & 8.2 \\
\hline
\end{tabular}

\subsection{Ethnic and Religious Composition of the Respondents}

The ethnic composition of the respondents is given (Table 5).

Table 5. Ethnic composition of the respondents

\begin{tabular}{|c|c|c|c|c|c|c|}
\hline & & \multicolumn{4}{|c|}{ School Name } & \multirow{2}{*}{ Total } \\
\hline & & School CA & School CB & School IA & School IB & \\
\hline \multirow{7}{*}{ Caste } & Brahmin & 13 & 8 & 14 & 12 & 47 \\
\hline & Chhetris & 23 & 19 & 26 & 21 & 89 \\
\hline & Gurung/Magar & 11 & 7 & 11 & 9 & 38 \\
\hline & Newar & 31 & 29 & 35 & 22 & 117 \\
\hline & Tharu & 7 & 5 & 7 & 5 & 24 \\
\hline & Others & 7 & 4 & 9 & 5 & 25 \\
\hline & Total & 92 & 72 & 102 & 74 & 340 \\
\hline
\end{tabular}

Table 6. Religious composition of the respondents

\begin{tabular}{|c|c|c|c|c|c|c|}
\hline & & \multicolumn{4}{|c|}{ School Name } & \multirow{2}{*}{ Total } \\
\hline & & School CA & School CB & School IA & School IB & \\
\hline \multirow{6}{*}{ Religion } & Hindu & 49 & 36 & 55 & 44 & 184 \\
\hline & Buddhist & 22 & 18 & 24 & 17 & 81 \\
\hline & Christian & 6 & 5 & 7 & 3 & 21 \\
\hline & Islam (Muslim) & 8 & 7 & 9 & 6 & 30 \\
\hline & Others & 7 & 6 & 7 & 4 & 24 \\
\hline & Total & 92 & 72 & 102 & 74 & 340 \\
\hline
\end{tabular}

The religious composition of the respondents in relation to the religion shows that majority of the students follow Hinduism and least of them follow Christianity.

\subsection{Parents' occupation of the respondents}

The occupation of parents among the respondents is on the table below.

Research studies show that teaching and learning of science are influenced by the parents' occupation. Most of the parents in both the community and institutional schools are engaging in farming. High school students learn the basic concept of science more easily and effectively from the farmers' families than that of the other profession. It shows us that the great possibility of science learning from the community and livelihood practices. However, subject experts and practitioners need to link the common but basic community practices in the science curriculum. 
Table 7. Parents' occupation

\begin{tabular}{|c|c|c|c|c|c|c|}
\hline & & \multicolumn{4}{|c|}{ School Name } & \multirow{2}{*}{ Total } \\
\hline & & School CA & School CB & School IA & School IB & \\
\hline & Farmer & 29 & 22 & 34 & 23 & 108 \\
\hline & Labour & 8 & 7 & 8 & 5 & 28 \\
\hline & Teacher & 13 & 11 & 16 & 12 & 52 \\
\hline \multirow[t]{4}{*}{ Occupation of parents } & Have own land & 24 & 18 & 25 & 24 & 91 \\
\hline & Driver & 4 & 3 & 4 & 6 & 17 \\
\hline & Doctor & 9 & 7 & 9 & 1 & 26 \\
\hline & Others & 5 & 4 & 6 & 3 & 18 \\
\hline Total & & 92 & 72 & 102 & 74 & 340 \\
\hline
\end{tabular}

\section{Conclusion}

This study report results from 340 students of grade ten and their parents from four high schools (two from urban and two from rural areas) in Nepal. They participated in providing opinions about the application of simple machines to daily life activities. The data were collected in the winter of 2018 and analyzed in the summer by using the same set of questions. Furthermore, an interview was carried out with the parents in the summer of 2018 for the same purpose to measure the students' overall livelihood experiences in home to engage in hands-on activities to understand the concept of science related to the tenth-grade science curriculum. They predicted three science-related outcomes: meaningful engagement in the classes and community practices, understanding basic science concepts, and science identity from cultural and ethnic practices. The findings suggested that home-based livelihood practices of parents show potentials for supporting students' engagement and learning in science lessons and in nurturing students' curiosity in pursuing science to understand concepts in science better.

As the concerns of the Government of Nepal and science teacher educators are growing based on the underachievement of students in SEE, the application of home activities to the learning of the basic concept of science over the last few years provides an opportunity to scale up by meaningfully engaging high school students in trustworthy, everyday learning of science concepts and nurturing the high school students' interest in science as a subject and its basic concepts with complete home-based learning. This study highlights the role of students' views of themselves as experiencers, and self-directed in the livelihood practices, as well as their science learning motivation and engagement in the kitchen practices, grain conservation techniques which are indirectly linked to scientific concepts, and application of herbs to grain conservation as well as medical practices at every home in the communities either in the urban or rural parts of Nepal. These activities motivate high school students to understand basic science concepts. Therefore, as part of science teaching methodology, this concept will be beneficial in recognizing some of the techniques in classroom pedagogy, science curriculum, and also the public interactions among the students, teachers and parents. The findings of this research recommend that the learners' home-based socio-cultural involvement can beneficially be extended to the learning of science in the classroom and vice versa.

\section{Acknowledgements}

The study presented here is based on Small Research Development and Innovation Grants (SRDIG) to the faculty member supported by the University Grants Commission (UGC), Nepal. So, I would like to thank to the members of the research unit, UGC. Similarly, I would like to acknowledge Prof. Dr. Kedar Man Shrestha, Prof. Dr. Sarada Devi Maharjan, Prof. Dr. Rukmini Bajracharya, Prof. Dr. Hridaya Ratna Bajracharya, Prof. Dr. Shovakanta Lamichhane, Prof. Dr. Lila Pradhan and Prof. Dr. Krishna Bhakta Maharjan for the scholarly guidance. My special thanks go to Associate Professor Kamal Kumar Poudel for his insightful guidance and language edition of the paper. Also, I am thankful to all the research participants.

Any opinions, findings, and conclusions made here are those of the authors and do not necessarily reflect the views of the Ministry of Education, Nepal Government.

\section{References}

Acharya, K. P. (2018). Inquiry-based Science Learning through School Gardening Activities: Wonderful Experience Through Participatory Action Research. International Journal of Elementary Education, 7(3), 40-45. https://doi.org/10.11648/j.ijeedu.20180703.11

Acharya, K. P., Devkota, B., Budhathoki, C. B., \& Bjonness, B. (2018). Relevance of Learning Science through Inquiry-based Participatory Action Research in Basic Public Schools of Nepal: A Proposal. The Online 
Journal of New Horizons in Education, 8(4), 87-97. Retrieved May 1, 2019, from http://www.tojned.net/journals/tojned/articles/v08i04/v08i04-09.pdf

Adejimi, S. A. (2019). Ethno-science and globalization. In Globalized Curriculum Methods for Modern Mathematics Education (pp. 136-144). IGI Global. https://doi.org/10.4018/978-1-5225-6158-3.ch010

Alim, A., Sarwi, S., \& Subali, B. (2020). Implementation of ethno-science based guided inquiry learning on the scientific literacy and the character of elementary school students. Journal of Primary Education, 9(2), 139-147.

Black, R., Weiler, B., \& Chen, H. (2019). Exploring theoretical engagement in empirical tour guiding research and scholarship 1980-2016: A critical review. Scandinavian Journal of Hospitality and Tourism, 19(1), 95-113. https://doi.org/10.1080/15022250.2018.1493396

Chen, C. H. (2019). The impacts of peer competition-based science gameplay on conceptual knowledge, intrinsic motivation, and learning behavioral patterns. Educational Technology Research and Development, 67(1), 179-198. https://doi.org/10.1007/s11423-018-9635-5

Chowdhury, M. (2018). Emphasizing morals, values, ethics, and character education in science education and science teaching. MOJES: Malaysian Online Journal of Educational Sciences, 4(2), 1-16.

Dewey, J. (1998). The essential Dewey: Pragmatism, education, democracy (Vol. 1). Indiana University Press.

Engeström, Y. (2017). Expanding the scope of science education: An activity-theoretical perspective. In Cognitive and Affective Aspects in Science Education Research (pp. 357-370). Springer, Cham. https://doi.org/10.1007/978-3-319-58685-4_26

Hargreaves, T., Wilson, C., \& Hauxwell-Baldwin, R. (2018). Learning to live in a smart home. Building Research \& Information, 46(1), 127-139. https://doi.org/10.1080/09613218.2017.1286882

Hong, Y. L., \& Talib, C. A. (2018). Scientific Argumentation in Chemistry Education: Implications and Suggestions. Journal of Asian Social Science, 14(11), 16-29. https://doi.org/10.5539/ass.v14n11p16

Hussin, W. T., JHarun, J., \& Shukor, N. A. (2019). Problem Based Learning to Enhance Students Critical Thinking Skill via Online Tools. Asian Social Science, 15(1), 14-23. https://doi.org/10.5539/ass.v15n1p14

James, J. K., \& Williams, T. (2017). School-based experiential outdoor education: A neglected necessity. Journal of Experiential Education, 40(1), 58-71. https://doi.org/10.1177/1053825916676190

Kelly, G. J., \& Licona, P. (2018). Epistemic practices and science education. In History, philosophy and science teaching (pp. 139-165). Springer, Cham. https://doi.org/10.1007/978-3-319-62616-1_5

Liou, P. Y., \& Jessie Ho, H. N. (2018). Relationships among instructional practices, students' motivational beliefs and science achievement in Taiwan using hierarchical linear modelling. Research Papers in Education, 33(1), 73-88. https://doi.org/10.1080/02671522.2016.1236832

Rahmawati, S., Subali, B., \& Sarwi, S. (2018). The effects of ethno-science based contextual learning towards students' learning activity. Journal of Primary Education, 8(2), 152-160.

Rouse, J. (2018). Engaging science: How to understand its practices philosophically. Cornell University Press. https://doi.org/10.7591/9781501718625

Sudarmin, S., Selia, E., \& Taufiq, M. (2018). The influence of inquiry learning model on additives theme with ethno-science content to cultural awareness of students. In Journal of Physics: Conference Series (Vol. 983, No. 1, p. 012170). IOP Publishing. https://doi.org/10.1088/1742-6596/983/1/012170

Sumarni, W. (2018). The influence of ethno-science-based learning on chemistry to the chemistry's literacy rate of the prospective teachers. Unnes Science Education Journal, 7(2).

Vedder-Weiss, D., \& Fortus, D. (2018). Teachers' mastery goals: Using a self-report survey to study the relations between teaching practices and students' motivation for science learning. Research in Science Education, 48(1), 181-206. https://doi.org/10.1007/s11165-016-9565-3

\section{Copyrights}

Copyright for this article is retained by the author(s), with first publication rights granted to the journal.

This is an open-access article distributed under the terms and conditions of the Creative Commons Attribution license (http://creativecommons.org/licenses/by/4.0/). 